\title{
Research on Religious Dissemination in Universities
}

\author{
Hong Huo \\ Student Affairs Office, Shenyang University \\ No. 21 Wanghuan South Street Dadong District, Shenyang 110044, China \\ Tel: 86-24-6226-8411Ｅ-mail: huohong@163.com
}

Linlin Sun

Culture and Media College, Shenyang University

No. 54 Lianhe Road Dadong District, Shenyang 110041, China

Tel: 86-24-6226-7982Ｅ-mail: sunlinlin@126.com

\begin{abstract}
Dissemination of religion is a serious challenge to the management of universities in our country. According to the literature review, authors of this article sort out the proportion of students in part of universities who have religious beliefs, and get the result that the proportion of such students is approximately ten percent. In the mean time, the authors made a deep analysis of features religious dissemination in the dissemination subject, dissemination mode and dissemination means. It is found that Christianity has become the subject of religious the dissemination in universities, mass communication has turned to be the major means and platform for religions to be disseminated in universities and such interpersonal dissemination forms as "family gathering", indirect contact and E-mail, etc, have become the primary forms of religious dissemination. Furthermore, they pointed out, leaders of universities should attach great importance to modernization, concealment and diversification of religious dissemination in universities and try to deal with them as the circumstances may require.
\end{abstract}

Keywords: Management of universities, Religious dissemination, Disseminative mode

\section{Background of research}

China is not only a country with multiple religions, but a nation in which its citizens can freely choose and express their beliefs and demonstrate their religious identity. Freedom of religious belief is not only a policy of the Communist Party of China, but is also one of citizen rights stipulated by "Constitution", one that can be shared by university students and other citizens in China.

Considering the statistical data about religious belief condition of university students in all areas in China, we can discover that, the highest proportion of university students who have a religious belief is $28.4 \%$, the lowest is approximately $6.8 \%$ and mostly is $10 \%$ or so. For details, please see Table 1 .

\section{Insert Table 1 Here}

Although proportions of university students who have a religious belief in all areas indicated in Table are different, even with great discrepancy, these data have not only fully proved that university students share the right of freedom of religious belief, but have reflected a fact that the issue of university students who have a religious belief can not be ignored.

Although university students can fully share the right of freedom of religious belief, it is totally different from allowing dissemination of religions on the campus. In order to guarantee realization of freedom of religious belief, the country has carried out the principle of separation of Church and State and separation of religion and education. Legally, it is not prohibited to conduct religious propaganda, set up religious organizations and organize religious activities in state organs, public occasions and state-run schools. However, religious dissemination in universities has not been ceased owing to legal prohibition. As a matter of fact, religious dissemination in universities still exists explicitly or implicitly in a variety of forms and plays an important role. 


\section{Major issues in religious dissemination in universities}

It is discovered after a comprehensive analysis of investigations in all areas that, there are mainly three issues in religious dissemination in universities.

\subsection{Christianity has become the main force of religious dissemination in universities and its spread and momentum of growth is swift and violent.}

On the campus, what university students are mostly devoted to and fascinated in is Christianity. In his investigation in Wenzhou University, Chen Jin'an indicated, among the 210 university students who declared clearly to have a religious belief, there were 130 who believed in Christianity (including Catholicism, Protestantism and Eastern Orthodoxy), approximately accounting for $62 \%$ of all those who have a religious belief. Among university students who have a religious belief in the three universities in Qinhuangdao, proportion of students who believe in Christianity (including Catholicism) also attained 36.3\%, ranking second only to the proportion of students who believe in Buddhism (with a proportion of $41.4 \%$ ). Furthermore, Zheng Aiping in Zhejiang University also pointed out clearly in the investigation in university students of more than 40 majors in several universities in Zhejiang, Beijing, Shanghai and Nanjing, etc, including Arts, Science, Engineering, Agriculture and Medicine, etc, although the number of university students who believed in Buddhism (having the tendency) reflected through questionnaire exceeded the number of those who believed in Christianity (having the tendency), we found out through interview that, the actual number of those who believed in Christianity (having the tendency) might exceed the number of those who believed in Buddhism (having the tendency), and still had a further ascending trend. It was also discovered through the investigation that, those university students who had a religious belief had a relatively high degree of perseverance. When asked "Do you think religious belief can change your life", $71.2 \%$ students who believed in Christianity answered "Yes". When asked "if you believe in a certain religion and now you also want to join in the Communist Party of China, will you abandon your religious belief", 73.7\% students who believed in Christianity would answer "No".

\subsubsection{Religious and cultural dissemination of Christianity is unimpeded.}

Through research, we found out that, on the campus today, influences and expansion of Christianity among university students are not indicated as the fact that some students become a convert and believe in a religion, but more importantly are manifested as the result that successful dissemination of religious culture of Christianity in the campus directly leads to changes of university students in their religious knowledge and attitude. In 2001, in relative questionnaire investigation in Renmin University of China, Yang Huilin indicated that, those who clearly showed that they had a religious belief accounted approximately for $3.6 \%$. In the mean time, there were about $61.5 \%$ university students expressed that, "they did not believe in Christianity, but took interest in Christianity".

We found out through interview that, in daily life, university students are disseminating some popular fashions with the connotation of religious culture of Christianity with or without consciousness, such as wearing a cross necklace and a bracelet and a T shirt with cultural connotation of Christianity, going to the Church to listen to the hymn for a whole, reading and discussing the story of Bible and having festivals of Christianity. In dissemination of these religious cultures, what university students are most zealous is their pursuit of festivals of Christianity, such as Christmas Day party, dining together on the Easter Day and sending cards on the Thanksgiving Day, etc, which are quite prevalent among university students. Especially on Christmas Day each year, quite a large number of university students fall into company with each other and crowd into the Church to appreciate the atmosphere of the religion. Churches in some cities are crowded to their capacity. With unconscious edification of these religious cultures, university students can get access to ideas and thoughts of some religions more or less, and compared with other students, they are more likely to become one who believes in a religion.

\subsubsection{Religious dissemination of Christianity is in the ascendant.}

The critical philosophical and social science project "Survey of Spiritual Life of Contemporary Chinese" which was conducted by the Ministry of Education in the summer holiday in 2005 indicates, the major religions in China are Buddhism, Taoism, Catholicism, Christianity and Islam, with a number of population accounting for $67.4 \%$ of the total population believing in religions. There are 200 million who believe in Buddhism and Taoism and worshippers in stories of the Dragon King and Mammon, etc, accounting for $66.1 \%$ of all the population believing in religions. There are 16 million believing in Catholicism and 40 million believing in Christianity (accounting for $12 \%$ of all population believing in religions). It can be said, since the reform and opening up, the dramatic increase of Christianity in China can not be separated with Christians bound up in preaching their religions. 
Christianity is a kind of extravert religion. In "Bible", Jesus encouraged his believers to evangelize everywhere and bear "fruit" (namely, developing believers). The more "fruits" one bears, the more he feels honored before God. All Christians have soaring preaching enthusiasm, including the group of university students who throw themselves into preaching on the campus one after another. On the other hand, university students seem obviously dubious in their attitude towards preaching by propagators. In the survey made by Zheng Aiping, there were 304 people (accounting for 19.5\%) who answered "being interested in culture of Christianity". When university students who have no Christianity belief are faced up with preaching by students who have Christianity belief, there were 120 people who expressed that "this can help them to understand Christianity, regard belief in a religion as an option of life and it is helpful for them to make a decision by listening to preaches and reading some scriptures." And there were only 50 people who clearly expressed that "they would excuse themselves from listening to preaches or find an excuse to escape." However, most universities do not have definite or effective resolutions to treat with students who are wild about preaching, but just persuade them to leave the school after receiving reports from other students.

In addition to university students who preach, there are also some foreign nationalities and people from the society who enter the campus to preach whose preaching means are more varied. In one word, with unremitting efforts by preaching personnel, development of Christianity exhibits an ever-ascending trend in universities.

2.2 The mass media become the primary platform and means of religious dissemination in colleges, with obvious dissemination effect.

Traditional mass media include broadcast, TV, book, magazine, newspaper and movie. With approaching of the era of Internet, the network medium with the carrier of Internet has become the fourth major medium paralleling with newspaper, broadcast and TV. These seven kinds of mass media play their own role in religious dissemination on the campus. Various religious powers and groups make use of network and broadcast to dispatch or deliver religious books, leaflets and CDs to disseminate religious doctrine or some anti-Marxism or anti-science content.

2.2.1 Network has become the primary means for religious dissemination on the campus.

Internet is a multi-media platform, with advantages of rapid dissemination, good interactivity and obvious dissemination effect, etc. Religious disseminators employ network to set up religious websites and propagandize religious knowledge and religious thoughts by means of detailed word introduction, music video with combination of audio and video and polychrome pictures. In the mean time, they resort to personal blog for religious dissemination and make use of BBS for mutual discussion and communication to continue to expand their influential power. As the major user of network, university students have quite convenient conditions for surfing on-line on the campus, not only having Campus Network, but also have broadband network and even wireless network, etc. This, to a certain extent, provides necessary conditions for networked dissemination of religions on the campus. University students can conveniently browse a variety of religious websites on the campus and express their opinions and communicate with their religious friends, seldom intervened or interrupted. Thus, the role of network in religious dissemination is on a daily increase.

\subsubsection{Traditional religious books are still the most powerful medium for religious dissemination.}

It is the primary means for all sorts of religious disseminations to preach by means of traditional media, such as books. Each religion has its own religious classics. The reason for these books to become the most traditional media of religious dissemination is that they have the advantages of being systematic in knowledge, specific, authoritative and convenient to bring. Since university students have high learning capacity and reading capacity, some religious books have become fast-selling shopping-rush goods among university students since the earlier 1980s. Let's take "Bible" in Christianity and reading materials of "Bible" as an example. It is said, in the last twenty years, Christianity has red "Bible" for its believers and has printed hundreds of thousands of "Bible" for sale in the church, but most of them have been purchased by those who are not Christians and quite a lot of whom are university students attracted by the western culture represented by Christianity. Story books compiled according to various scriptures are more favored. "Bible Stories" compiled and translated by a scholar has been printed and distributed up to 1 million volumes, with a group of readers who are universities students having certain culture foundation and having deep interest in western culture. Circulation of these books among university students has played a role that can not be ignored in religious dissemination.

In addition to utilization of traditional religious books, a religion also makes use of mailing various propaganda materials to disseminate its doctrine, such as leaflet, audio tape and CD, etc. Usually, these propaganda materials are made quite exquisite and most are discharged free of charge. University students are often confused by beautiful appearance of these materials, read their content and circulate these materials, but seldom report these materials. 
2.2.3 Films and television programs with the content of religion have become potential helpers of religious dissemination.

Religious environment, religious influences and religious culture presented by films and television programs have an unconscious facilitation effect on religious dissemination among university students, for example, quietness of the temple, holiness of the church, placidness of siongking, melodiousness of singing hymns and piety of confession, let alone the various mysterious manifestation presented in films and television programs, which, without doubt, are a great seduction to those university students who have no experience of life in a changeable world.

\section{3 "Family gathering" interpersonal dissemination becomes the primary form of religious dissemination, with} covert dissemination form.

University students often take religious belief as a matter of "personal sphere" and regard interpersonal dissemination as the primary dissemination means, with strong elusiveness and persuasion.

\subsection{1 "Family gathering" becomes the most cozy form of religious dissemination on the campus.}

It is proved through investigation that, university student Christians mainly participate in religious activities by individual behavior and small team behavior. Through the family gathering of "discussion by several people or scores of people to lead a religious life together", the influence of Christianity on university student Christians is gradually on the increase. During the investigation, merely $17 \%$ student Christians said that, they lead their own religious life in the form of "family gathering". However, in interview with them, their recognition and feeling of this form is enough to be concentrated.

These family churches of "family gathering" are scattered around the campus and surrounding and most of university Christians can directly participate and care of members about each other is fully reflected. Those with similar age and interest get together, which can not only enable them to sermon together, sing hymns, study Bible and pray, but can also make them have extensive and deep communication about various issues from religious belief to life. Besides, quite a lot of house churches often hold some rich and eclectic activities, such as autumn outing, timeless party, and inviting experts to impart the knowledge of theology and "suffrage" for those church members encountered with some problems, etc. Under this comfort and loose party atmosphere, for those "catechumen" and "followers of religious culture" who have just joined in a religion, propagators, first of all, make friends with them with sincerity, then penetrate the religious thought into them in the process of becoming friends and finally occupy the mind of university students.

2.3.2 To disseminate religions through such disguised means of economic subsidization, foreign language learning and knowledge impartation, etc.

Some propagators make use of the opportunity of collective celebration on entry into universities of students or subsidization on those students who have difficulties in family economy, with the purpose of enabling people to believe their kindness, universal love and kind motive, reinforcing their favorable impression on and interest in them and disseminating religions and absorbing members.

In the mean time, some religious organizations make use of the psychology of some university students to be eager to master the spoken English language and new academic concepts to sneak into English Corner and academic Salon to communicate with university students, so as to propagandize their religious doctrine and canon and achieve their purpose of propagandizing the religious doctrine.

In addition, some foreign teachers themselves are religious believers. When they teacher a class and communicate with students, they always impart knowledge about religious to their students with or without intention, such as, religious architecture, religious dance and music, etc, to gain favor of university students and to convey religious concepts to their students.

\subsubsection{To dissemination religions through sending e-mail and correspondence, etc.}

Both traditional correspondence and telephone conversation and modern email, QQ talk and MSN belong to the scope of interpersonal dissemination. These convenient communication forms are also extensively used by propagators. Especially, they use such means as e-mail based on Internet to contact with university students, which makes their propaganda effects more rapid and effective. Virtuality of Internet also makes it difficult for university students to distinguish between its true and false and between good and evil, and easier for them to accept it. Furthermore, as a result of vulnerability of network management, it is difficult to supervise and watch religious penetration by means of Internet and this is more helpful to achieve the purpose of preaching. 


\section{Conclusion}

As for the issue of religious dissemination in colleges and universities, we should neither turn a blind eye to it and let things slide or drift, nor apprehend danger in every sound. On the contrary, we should conduct management of religious affairs in colleges and universities pursuant to the law based on characteristics of education and management in colleges and universities and take a positive attitude in leading universities students to adapt to the socialism society. On one hand, on the basis of respecting religious beliefs of universities students, the schools should lead them to live a legal religious life through pertinent ideology education and encourage them to give explanation about religious doctrine that is conducive to the socialism spiritual civilization establishment, emphasize family ethics, practical rationality and harmony and practice what they preach, which should become examples among university students that are devoted to learning and committed. On the other hand, university students should be on guard against all sorts of illegal religious dissemination activities inside and outside the campus, especially vigorously restraining and attacking reactionary political force inside and outside the border who make use of religious penetration to conduct anti-Party and anti-people secessionist activities.

\section{References}

Chen, Jin'an. (2004). Analysis of Causes for Religious Beliefs among University Students and Their Countermeasures. Beijing: Science and Atheism, (01), p.49.

Dong, Dong. Summary of Study on Issues of Religious Beliefs among University Students. [Online] Available: http:// www.fjdh.com/wumin/HTML/94960.html.

High Attention to and Cautious Treatment of Religious Beliefs among University Students. [Online] Available: http://www.kankan.com.cn/SuperLibtary/chargearticle.asp?AID=2007.

How is the Situation of Religious Beliefs among University Students. [Online] Available: http://blog.163.com/qq401287956/blog/static/41126336200902113831901/\#.

Li, Zhaowen \& Zhou, Hongyan. (2006). Sociology Analysis of the Phenomenon of Dubiety of Religions among University Students. Harbin: Journal of Harbin University, (05).

Li, Zhiying. (2007). Trend of Thought of University Students Who Believe in Religions and Analysis of Causes. Beijing: Contemporary World \& Socialism, (01).

Yang, Huilin. Characteristics of Understanding in Christianity by Contemporary University Students. [Online] Available: http://www.regentcsp.org/list_bbs.asp?id=287 (March 2, 2005).

Zhao, Bin. (2001). Perspective in the Phenomenon of Dubiety of Religions among University Students. Shanghai: Journal of Donghua University (Social Science Edition), (02).

Zheng, Aiping. Several Issues to be Focused in the Phenomenon of Religious Beliefs among University Students. [Online] Available: http:// www.cycs.org/InsInfo.asp?InsID=19\&ID=.

Zuo, Peng. (2006). Analysis of Religious Beliefs among Contemporary University Students. Shanghai: Journal of Ideological \& Theoretical Education, (09), p.41-43. 
Table 1. The proportion of university students who have a religious belief in all areas

\begin{tabular}{|c|c|c|c|}
\hline $\begin{array}{l}\text { Time of } \\
\text { investigation }\end{array}$ & $\begin{array}{l}\text { Place of } \\
\text { investigation }\end{array}$ & Investigator/Name of the project & $\begin{array}{l}\text { The proportion of } \\
\text { students who have } \\
\text { a religious belief }\end{array}$ \\
\hline 1998 & Beijing & $\begin{array}{l}\text { Investigation of young people in Beijing who have a } \\
\text { religious belief and study on countermeasures }\end{array}$ & $13.4 \%$ \\
\hline 2000 & Shanghai & $\begin{array}{l}\text { Study on problems of university students at a deep } \\
\text { level }\end{array}$ & $11.8 \%$ \\
\hline 2003 & Beijing & $\begin{array}{l}\text { Relative investigation in religious beliefs in Minzu } \\
\text { University of China }\end{array}$ & $28.4 \%$ \\
\hline 2004 & Beijing & $\begin{array}{l}\text { "Investigation and Analysis in Status Quo of } \\
\text { University Students" Religious Beliefs in Beijing" by } \\
\text { Guo Shumin }\end{array}$ & $24.74 \%$ \\
\hline 2004 & $\begin{array}{l}\text { Wenzhou } \\
\text { University }\end{array}$ & Chen Jin'an & $10 \%$ \\
\hline 2005 & $\begin{array}{l}10 \text { universities in } \\
\text { Beijing }\end{array}$ & $\begin{array}{l}\text { "Investigation in Polarization of Social Classes in } \\
\text { Contemporary China and Ideological Trend of } \\
\text { University Students" by Li Zhiying et al }\end{array}$ & $13.58 \%$ \\
\hline 2005 & Hefei & $\begin{array}{l}\text { Heifei University in Anhui "Investigation in } \\
\text { Religious Belief Condition of Contemporary } \\
\text { University Students" }\end{array}$ & $6.8 \%$ \\
\hline 2007 & $\begin{array}{l}5 \text { universities in } \\
\text { Hebei Province }\end{array}$ & Zhao Zongbao et al & $11.14 \%$ \\
\hline 2007 & $\begin{array}{l}18 \text { universities in } \\
\text { Guangdong } \\
\text { Province }\end{array}$ & Xian Deqing & $19.1 \%$ \\
\hline 2008 & Jinan University & Lu Yuan et al & $9 \%$ \\
\hline 2009 & $\begin{array}{l}\text { Three universities } \\
\text { in Qinhuangdao }\end{array}$ & $\begin{array}{l}\text { How is the condition of university students who have } \\
\text { a religious belief }\end{array}$ & $12.4 \%$ \\
\hline
\end{tabular}

